\title{
Efeitos neuroprotetores do diltiazem em coelhos com oclusão da aorta
}

\author{
Neuroprotective effects of diltiazem in rabbits with occluded aorta
}

Tonguc SABA ${ }^{1}$, Sinasi MANDUZ ${ }^{1}$, Ismail SAPMAZ ${ }^{1}$, Ali TUNEL ${ }^{1}$, Handan AKER ${ }^{2}$, Kasim DOGAN $^{3}$

RBCCV 44205-923

\section{Resumo}

Objetivo: O objetivo do presente trabalho é determinar o efeito protetor da perfusão na aorta distal com diltiazem e solução de Ringer lactato na medula espinal.

Métodos: Foram usados 27 coelhos da raça New-Zeland, nos quais se provocou isquemia da medula espinal por meio de oclusão da aorta durante 30 minutos. Os animais experimentais foram divididos em quatro grupos: grupo A $(n=4)$, o grupo de cirurgia simulada (pseudocirurgia); o grupo B $(n=8)$ no qual se aplicou somente a oclusão do balão intraaórtico; grupo C (n=7), o grupo do Ringer lactato, no qual a solução de Ringer lactato foi perfundida na aorta distal após oclusão do balão intra-aórtico; grupo $D(n=8)$, grupo do dialtiazem, no qual $40 \mathrm{mg} / \mathrm{kg} / \mathrm{h}$ de diltiazem, em solução de Ringer lactato, foram perfundidas na aorta distal após oclusão do balão intra-aórtico. A função motora dos membros posteriores foi avaliada pelo sistema de escore de Tarlov. Após observação, as medulas espinais foram removidas para avaliação histopatológica.

Resultados: O grau de lesão histopatologica estava bem correlacionado com a função neurológica. Lesões histopatológicas e disfunções neurológicas mais graves ocorreram no grupo B, seguido pelos grupos C, D e A, respectivamente. Não ocorreu nenhuma lesão ou disfunção neurológica no grupo de cirurgia simulada.

Conclusões: $O$ efeito protetor do diltiazem na lesão histopatológica e na função neurológica foi significativo em comparação com os grupos-controle.

Descritores: Reperfusão. Aorta. Modelos animais.

1. Doctor, Researcher

2. Professor, Pathologist.

3. Professor, Consultant, Main Director.

Trabalho realizado na Cumhuriyet Universitesi, Turkey.

Endereço para correspondência:

Dr. Ýsmail Sapmaz. kalp ve damar cerrahisi. Sivas 58140 Turkey.

Fone: +90 5335158084 .

E-mail: sapmaz@cumhuriyet.edu.tr 


\begin{abstract}
Objective: In the present study, we aimed to determine the protective effect of the perfusion of the distal aorta with diltiazem and ringer lactate solution on the spinal cord.

Methods: Twenty-seven New Zealand rabbits were used in which spinal cord ischemia was provided by occlusion of the aorta for thirty minutes. Experimental animals were divided into four groups: group $A(n=4)$, the sham operation group; group $B(n=8)$ in which intraaortic balloon occlusion alone was applied; group $C(n=7)$, ringer lactate group in which ringer lactate was perfused into distal aorta at a rate of $40 \mathrm{ml} / \mathrm{kg}$, hr, following intraaortic balloon occlusion; group $D(n=8)$ diltiazem group in which diltiazem $40 \mathrm{mg} / \mathrm{kg}$, hr, in Ringer lactate was perfused into distal aorta following
\end{abstract}

\section{INTRODUCTION}

Paraplegia due to ischemic spinal cord injury following cross clamping of the aorta remains to be the most feared complication of thoracoabdominal aortic surgery. Various techniques have been device for the protection of spinal cord during aortic occlusion, including shunt, bypass, local hypothermia, and pharmacologic interventions, alone or in combination but none provided a complete satisfaction. In the present study we aimed to determine the protective effect of the perfusion of the distal aorta with diltiazem and ringer lactate solution on the spinal cord.

\section{METHODS}

Thirty-two White New Zealand rabbits both of sexes, weighting between 1500 and 3000 gr. were used and experiments. An approve was got from Cumhuriyet University animal ethic committee. Spinal cord ischemia was provided by intraaortic balloon occlusion for 30 minutes. Five rabbits dropped out from experiments. Three of them died because of rupture of aorta while intraaortic balloon is being inflated. Two of them died while anesthesia induction. The remaining 27 rabbits were randomly assigned into groups:

1. Group $A(n=4)$ : Sham operation group in which only preoperative medication and surgical incision was done;

2. Group $B(n=8)$ : Ringer lactate was given intravenously during aortic balloon occlusion;

3. Group $\mathrm{C}(\mathrm{n}=7)$ : Ringer lactate group, in which ringer lactate $(4 \mathrm{mg} / \mathrm{kg} / \mathrm{hr})$ was perfused into distal aorta during occlusion; intraaortic balloon occlusion. Motor function of hind limbs was evaluated by Tarlov's scoring system. After observation, spinal cords were removed for histopathological evaluation.

Results: The degree of histopathological injury was well correlated with neurological function. The most severe histopathological injury and neurological dysfunction occurred in group B, followed by group C, D and A respectively. No injury or neurological dysfunction occurred in the sham group.

Conclusions: The protective effect of diltiazem on both histopathological injury and neurological function was significant in comparison with control groups.

Descriptors: Reperfusion. Aorta. Animal models.

4. Group $\mathrm{D}(\mathrm{n}=8)$ : Diltiazem group in which diltiazem ( 25 $\mathrm{mg} / \mathrm{kg} / \mathrm{hr}$ ). In ringer lactate was perfused into distal aorta. Heart rate was monitored before, during (in 10 minute intervals) and after aortic occlusion.

Ketamin (4-6 mg/kg/hr) was infused into the femoral vein by $18 \mathrm{~F}$ venous catheters, and heparin $100 \mathrm{IU} / \mathrm{kg}$ was infused into the catheter before ketamin infusion.

Balloon occlusion: A $3 \mathrm{~F}$ fogarthy arterial embolectomy catheter (Sorin Biomedical) was placed into distal aorta through femoral artery. Sufficient occlusion was judged by flattening of the pressure curve in distal aorta, and by increase in proximal aortic pressure. Inflation of the balloon with $0.2 \mathrm{ml}$ air for a width of $4-5 \mathrm{~mm}$ was sufficient. Place of balloon can be decided with dissected rabbits fore study previously. Inserted length of catheters were noticed and controlled if they were placed on corrected point of aorta while rabbit was being sacrificed.

Mean distal aortic pressure (m DAP) was monitored by a pressure transducer connected to the distal aorta by another $16 \mathrm{~F}$ catheter (Epidural catheter, Portex Ltd.) placed distally to the occlusion catheter, $8( \pm 1) \mathrm{cm}$ proximal to the femoral artery. Distal aortic pressure was measured before, during (at 10 minute intervals) and after occlusion. A catheter (22 G blue) was inserted into ear artery for to measure arterial pressure of proximal side of aortic occlusion (PAP).

In groups $C$ and $D$, distal catheter was used for infusion and DAP measurements by a three- way tap (Figure 1).

Body temperatures were measured both rectally and orally before, during (in 10 minutes intervals) and after aortic occlusion with glass thermometer with mercury.

After experiments the catheters were removed and skin was stitched. 


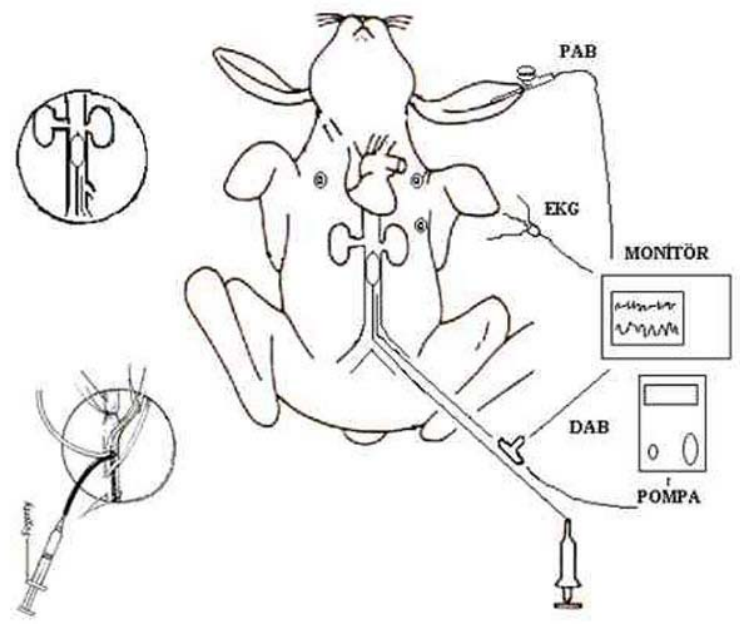

Fig. 1 - The experimental model for aortic occlusion

\section{Neurological evaluation}

Tarlov's score [1] evaluated during 48 hr observation period motor functions of the hind limbs as:

0 : No voluntary movement;

1: weak voluntary movements;

2: sittings by help;

3: sitting by self;

4: weak jumping;

5: normal jumping.

\section{Histopathological evaluation}

Following $48 \mathrm{hr}$ observation period animals were killed by intraperitoneal phenobarbital injection (150 mg/kg), and just after ensure animal died Bouin solution injected via intravenous way with pressure. Last procedure was done because of adequate histological fixation without time passed with sacrification of medulla spinalis with laminectomy. Following a laminectomy, spinal cord specimens from lumbar 2-5 level as distal spinal cord sample and T 6-10 levels as proximal spinal cord sample of $0.5 \mathrm{~cm}$ length were obtained and protected in Bouin's solution. Specimens were stained by hematoxylen x eosin. Sections were evaluated by a pathologist 'blindly'. Presence of ischemic changes and necrosis of motor cells of anterior horn was evaluated for definition of ischemic involving. Other changes evaluation were: degradation of Nissl substance and increase in basophilic staining in the cytoplasm, increase in perikarion volume, peripheral localization of nucleus, eosinophilic staining neurons containing pyknotic, angulated and shrinked nuclei.

Histopathological neuronal changes were graded as: grade I: Normal; grade II: presence of rare necrotic neurons; grade III: presence of widespread neuronal necrosis.

Grading was done according to the levels in which most severe ischemic changes occurred.

\section{Statistics}

Data were analyzed on SPSS 8.0 statistical program. Kruskal-Wallis test was used for evaluation of differences between experimental groups. Comparisons of results between paired groups were done by Mann-Whitney U test: Differences in heart rate, m PAP's, m DAP, body temperatures, and pathological changes were considered significant if $\mathrm{p}<0.05$.

\section{RESULTS}

\section{Heart rate}

An increase in heart rate occurred in group B and C animals following occlusion, which showed a decrease in $10^{\text {th }}$ minute, and reincreased in $20^{\text {th }}$ minute. In group D animals a decrease in heart rate followed occlusion which was attributed to diltiazem infusion, but heart rate increased above preoperative rate on $20^{\text {th }}$ minute.

Following the removal of occlusion heart rates were increased in group C and D animals, while it decreased in the group B animals (Table 1).

\section{Mean Proximal Arterial Pressures}

In group B, animals a steep increase in mPAP occurred following occlusion, and remained stable during occlusion.

In group C, animals a decrease in pressure occurred on $10^{\text {th }}$ minute, and remained stable during occlusion thereafter. In group D, animals increase in mPAP was less steep following and more stable during occlusion. A rapid drop in mPAP below pre occlusion values occurred in all occlusion groups.

Group differences evaluated by Kruskal-Wall's test showed no significant difference between groups (po. 851) - Table 2.

\section{Mean distal arterial pressure}

A rapid drop in mDAP following occlusion occurred in all groups, and remained stable during occlusion. Distal aortic perfusion had no effect on mDAP. An elevation occurred in all groups following removal of occlusion, but never reached to the preocclusion values.

Group differences were not significant $(\mathrm{p}=0.156)$ - Table 3 .

\section{Body temperatures}

Both oral and rectal temperatures decreased during occlusion in all groups, but rectal decrease was more prominent. Oral temperatures never decreased below 36C. Rectal temperature decrease were most prominent after $20^{\text {th }}$ 
minute. In groups with distal perfusion (group C and D) rectal temperatures dropped to as low as 34C towards the end of perfusion.

At $20^{\text {th }}$ minute, group differences in rectal temperatures between $\mathrm{B}$ and $\mathrm{D}, \mathrm{C}$ and $\mathrm{D}$ were significant, while the difference between $\mathrm{B}$ and $\mathrm{C}$ was not $(\mathrm{p}=0.34, \mathrm{p}=0.35)$ - Tables 4 and 5 .

Rectal temperature values were low in groups $\mathrm{C}$ and $\mathrm{D}$ in which distal aortic perfusion were done performed.

Table 1. Heart rates (beats per minute)

\begin{tabular}{lcccccc}
\hline Groups & Previous & 0. minute & $10^{\text {th }}$ minute & $20^{\text {th }}$ minute & $30^{\text {th }}$ minute & Pass \\
& $\mathrm{x} \pm \mathrm{SD}$ & $\mathrm{x} \pm \mathrm{SD}$ & $\mathrm{x} \pm \mathrm{SD}$ & $\mathrm{x} \pm \mathrm{SD}$ & $\mathrm{x} \pm \mathrm{SD}$ & $\mathrm{x} \pm \mathrm{SD}$ \\
\hline $\mathrm{B}$ & $161.25 \pm 11.2$ & $165.50 \pm 20.2$ & $155.87 \pm 19.1$ & $160.13 \pm 21.9$ & $154.37 \pm 16.2$ & $151.88 \pm 16.1$ \\
$\mathrm{C}$ & $1657 \pm 7.8$ & $170.43 \pm 18.6$ & $156.57 \pm 17,7$ & $165.00 \pm 29.3$ & $159.71 \pm 22.0$ & $169.71 \pm 22.4$ \\
$\mathrm{D}$ & $152.25 \pm 20.8$ & $147.63 \pm 30.3$ & $147.13 \pm 29.7$ & $166.00 \pm 29.0$ & $163.38 \pm 27.1$ & $168.13 \pm 14.8$ \\
\hline
\end{tabular}

$S D=$ standard deviation

Table 2. Mean proximal arterial pressures mPAP (mmHg)

\begin{tabular}{lcccccc}
\hline Groups & Previous & 0. minute & $10^{\text {th }}$ minute & $20^{\text {th }}$ minute & $30^{\text {th }}$ minute & Pass \\
& $\mathrm{x} \pm \mathrm{SD}$ & $\mathrm{x} \pm \mathrm{SD}$ & $\mathrm{x} \pm \mathrm{SD}$ & $\mathrm{x} \pm \mathrm{SD}$ & $\mathrm{x} \pm \mathrm{SD}$ & $\mathrm{x} \pm \mathrm{SD}$ \\
\hline B & $69.50 \pm 6.5$ & $80.75 \pm 20.4$ & $82.13 \pm 31.8$ & $80.63 \pm 29.8$ & $79.13 \pm 23.8$ & $53.87 \pm 12.8$ \\
$\mathrm{C}$ & $68.14 \pm 4.0$ & $83.71 \pm 18.4$ & $73.85 \pm 11.5$ & $76.14 \pm 12.7$ & $76.28 \pm 13.3$ & $55.00 \pm 13.0$ \\
$\mathrm{D}$ & $66.63 \pm 14.4$ & $75.25 \pm 17.3$ & $75.75 \pm 12.8$ & $76.38 \pm 18.4$ & $75.13 \pm 16.2$ & $54.50 \pm 13.4$ \\
\hline
\end{tabular}

$S D=$ standard deviation

Table 3. Mean distal arterial pressures (mmHg)

\begin{tabular}{lcccccc}
\hline Groups & $\begin{array}{c}\text { Previous } \\
\end{array}$ & 0. minute & $10^{\text {th }}$ minute & $20^{\text {th }}$ minute & $30^{\text {th }}$ minute & Pass \\
\hline B & $69.50 \pm 6.5$ & $12.37 \pm 4.2$ & $10.75 \pm 3.1$ & $10.62 \pm 2.3$ & $10.00 \pm 2.6$ & $53.87 \pm 12.8$ \\
C & $68.14 \pm 4.0$ & $14.00 \pm 3.8$ & $11.85 \pm 5.1$ & $13.71 \pm 3.3$ & $16.14 \pm 4.6$ & $55.00 \pm 13.0$ \\
D & $66.62 \pm 14.4$ & $13.00 \pm 3.2$ & $12.63 \pm 4.5$ & $10.75 \pm 3.8$ & $11.00 \pm 2.8$ & $54.50 \pm 13.4$ \\
\hline
\end{tabular}

$S D=$ standard deviation

Table 4. Oral temperatures $\left({ }^{\circ} \mathrm{C}\right)$

\begin{tabular}{lccccc}
\hline Groups & Previous & $10^{\text {th }}$ minute & $20^{\text {th }}$ minute & $30^{\text {th }}$ minute & Pass \\
& $\mathrm{x} \pm \mathrm{SD}$ & $\mathrm{x} \pm \mathrm{SD}$ & $\mathrm{x} \pm \mathrm{SD}$ & $\mathrm{x} \pm \mathrm{SD}$ & $\mathrm{x} \pm \mathrm{SD}$ \\
\hline $\mathrm{B}$ & $38.12 \pm 5.7$ & $37.81 \pm 6.2$ & $37.23 \pm 6.8$ & $36.72 \pm 7.8$ & $36.56 \pm 10.2$ \\
$\mathrm{C}$ & $37.80 \pm 6.9$ & $37.28 \pm 6.8$ & $36.87 \pm 3.8$ & $36.51 \pm 4.3$ & $36.51 \pm 3.5$ \\
$\mathrm{D}$ & $37.45 \pm 4.3$ & $37.13 \pm 6.8$ & $36.44 \pm 7.6$ & $36.27 \pm 5.6$ & $36.20 \pm 5.8$ \\
\hline
\end{tabular}

$S D=$ standard deviation

Table 5. Rectal temperatures $\left({ }^{\circ} \mathrm{C}\right)$

\begin{tabular}{lccccc}
\hline Groups & Previous & $10^{\text {th }}$ minute & $20^{\text {th }}$ minute & $30^{\text {th }}$ minute & Pass \\
& $\mathrm{x} \pm \mathrm{SD}$ & $\mathrm{x} \pm \mathrm{SD}$ & $\mathrm{x} \pm \mathrm{SD}$ & $\mathrm{x} \pm \mathrm{SD}$ & $\mathrm{x} \pm \mathrm{SD}$ \\
\hline $\mathrm{B}$ & $38.18 \pm 1.0$ & $37.20 \pm 0.9$ & $36.03 \pm 0.3$ & $35.15 \pm 0.8$ & $35.78 \pm 1.2$ \\
$\mathrm{C}$ & $38.14 \pm 0.5$ & $37.24 \pm 0.8$ & $35.85 \pm 0.2$ & $34.78 \pm 0.7$ & $35.55 \pm 0.4$ \\
$\mathrm{D}$ & $37.77 \pm 0.7$ & $36.73 \pm 0.6$ & $35.28 \pm 0.6$ & $34.31 \pm 0.6$ & $34.56 \pm 0.6$ \\
\hline
\end{tabular}

$S D=$ standard deviation

\section{Neurological evaluation}

All the animals in the control group (B) had complete paraplegia (Tarlov: 0) following experiments, lasting through $48 \mathrm{hr}$ observation period. None of the animals in group $\mathrm{D}$, and only one animal in group $\mathrm{C}$ had complete paraplegia. One animal in group $C$ and $B$ animals in group could jump normally after $48 \mathrm{hr}$ observation period.

In neurological evaluation, difference between $A$ and $C$ was not significant ( $\mathrm{p}=0.056$ ), while the differences between groups $A$ and $C$, $B$ and $C$, and $B$ and $D$ were significant $(p=0.016$, 0.020 , and 0.000 , respectively).

The degree of neurological dysfunction from the most severe and normal were ordered as groups B, C, D and A respectively (Table 6).

Table 6. Tarlov scores of groups

\begin{tabular}{lcccc}
\hline $\begin{array}{l}\text { Tarlov } \\
\text { Score }\end{array}$ & $\begin{array}{c}\text { A } \\
(\mathrm{n}=4)\end{array}$ & $\begin{array}{c}\text { B } \\
(\mathrm{n}=8)\end{array}$ & $\begin{array}{c}\mathrm{C} \\
(\mathrm{n}=7)\end{array}$ & $\begin{array}{c}\text { D } \\
(\mathrm{n}=8)\end{array}$ \\
\hline 0 & - & 8 & 1 & - \\
1 & - & - & 3 & 1 \\
2 & - & - & 2 & - \\
3 & - & - & - & 3 \\
4 & - & - & - & 1 \\
5 & 4 & - & 1 & 3 \\
\hline
\end{tabular}

\section{Histopathological evaluation of the spinal cord}

Among spinal cord sections the one with the most severe injury was considered representative for that animal. Sections from spinal cords of animals in the sham operations were found to be completely normal (Figures 2, 3 and 4). In all group B animals, there were grade III injury (complete widespread neuronal necrosis) - Figures 5, 6 and 7 . In group $C$, there were grade III injury in four animals. One animal from group $\mathrm{C}$ and three animals from group $\mathrm{D}$ had grade I injury. None of the animals in group D had grade III injury. Grades of histopathological injury were consistent with the degree of neurological dysfunction. Differences between groups $\mathrm{A}$ and $\mathrm{D}, \mathrm{A}$ and $\mathrm{C}, \mathrm{B}$ and $\mathrm{C}$, and $B$ and $D$ were all significant $(p=0.047$, $0.014,0.000$, and 0.033 , respectively). The sequence of the degree of injury from the most severe to normal were $\mathrm{B}, \mathrm{C}, \mathrm{D}$ and $\mathrm{A}$ respectively. 


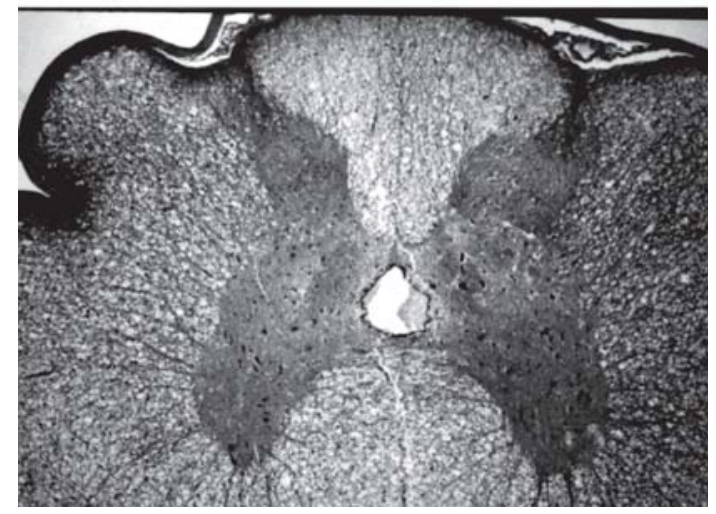

Fig. 2 - Sections from spinal cords of animals in the sham operations

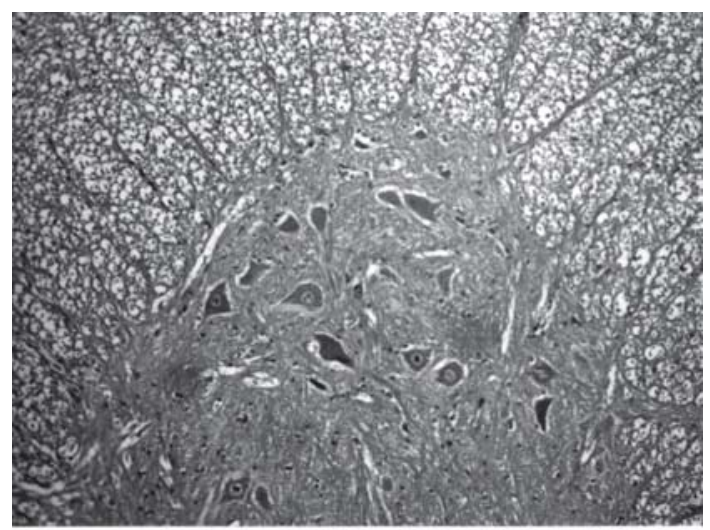

Fig. 3 - Sections from spinal cords of animals in the sham operations

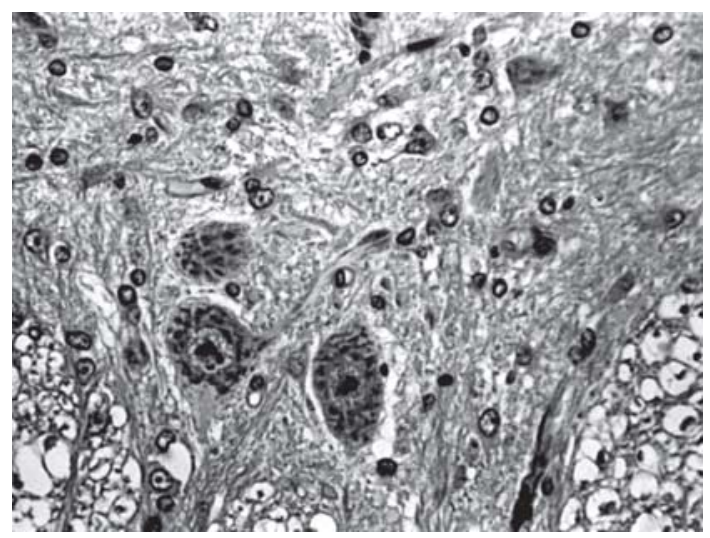

Fig. 4 - Sections from spinal cords of animals in the sham operations

\section{DISCUSSION}

Although, neurological dysfunction following infrarenal aortic operation is infrequent $(0.2 \%$ after elective surgery and $2.5 \%$ after ruptured aneurysm) it is as high as $40 \%$ after thoracoabdominal aortic surgery.

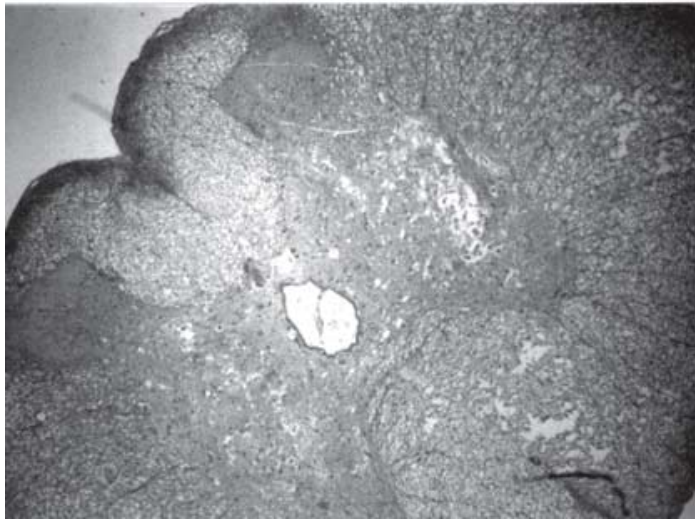

Fig. 5 - Animals with grade III injury (complete widespread neuronal necrosis)

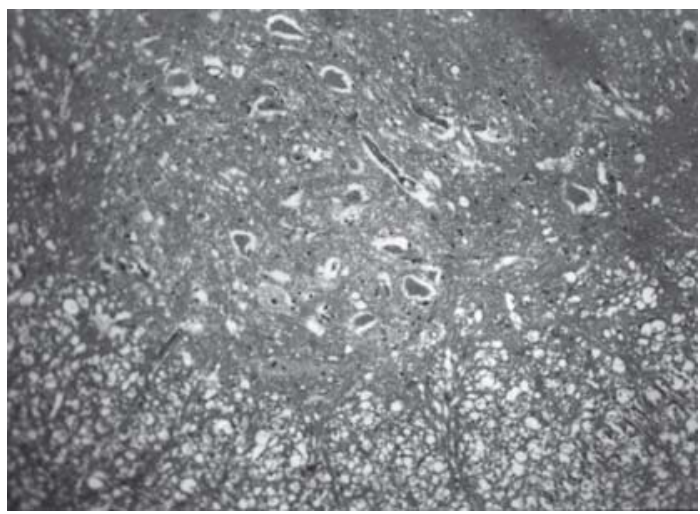

Fig. 6 - Animals with grade III injury (complete widespread neuronal necrosis)

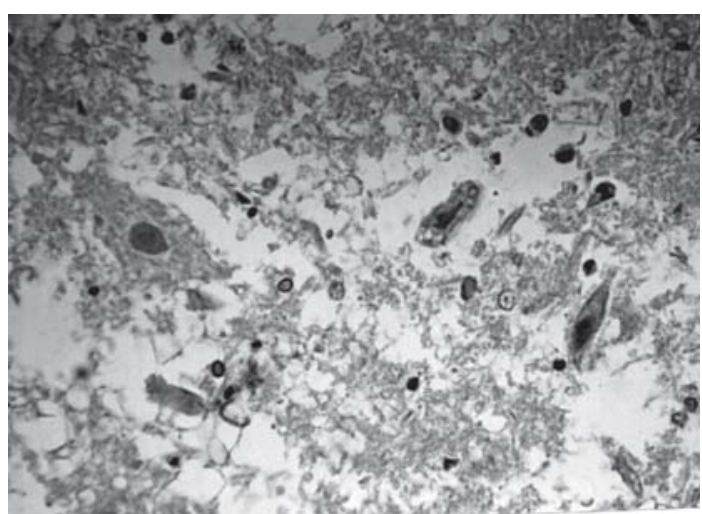

Fig. 7 - Animals with grade III injury (complete widespread neuronal necrosis)

Resulting in a cascade of chemical reactions intracellular calcium accumulation play a key role in the neuronal injury.

Several mechanisms have been proposed to play a role in prevention of spinal cord injury by calcium channel blocking agents:

1. Increase in cerebral and spinal blood flow enhances the 
access of glucose and oxygen into the tissues for oxygen and glucose synthesis;

2. Dilatation of longitudinal spinal arteries, particularly anterior spinal artery may dilatation to the prevention of injury;

3. Because (since) low distal perfusion pressure cannot counteract against the collapse of the arteries critical for the spinal cord perfusion, resulting vasoconstriction leads to the insufficient perfusion and thrombus formation. Vasodilatation may counteract against this effect;

4. By inhibition of voltage dependent calcium channels they prevent calcium inflow and its accumulation of calcium in the cytoplasm;

5. By preventing hypertension of calcium proximal to the cross clamping in aorta they may counteract against inadequate perfusion of the spinal cord;

6. Intracellular accumulation of calcium plays a key role in formation of free oxygen radicals which in turn leads to reperfusion injury (Transitions from type D to type B catalyzed by calcium ions).

Beneficial affect of calcium channel blockers occurs if they are administered before or immediately after spinal cord ischemia. Following central nervous system (CNS) ischemia they may lead to an increase in CNS blood flow resulting in improvement of neurological function [2].

Diltiazem was preferred because it is a specific blocker of L-type calcium channel, which is ubiquitous, and not specific for the nerve cells and arterial wall, it crosses bloodbrain barrier, is inexpensive and is readily available; antihypertensive, antiarrythmic and antianginal properties may be beneficial for conditions frequently associated with aortic disease; and because it has not previously been used for prevention of spinal cord injury.

Results of this study indicate to the presence of a significant difference between the diltiazem and the control groups both in the degree of injury and the neurological function and the degree of injury. In contrast, although the difference between diltiazem and sham operation groups was not significant for neurological function $(p=0.056$, $\mathrm{p}>0.05$ ) and histopathological changes were significant $(\mathrm{p}=$ $0.047, \mathrm{p}<0.05$ ) grade III neuropathological change has not been observed in these groups.

A number of physiopathological events play its role in spinal cord injury that is; embolisation and thrombosis of the critical arteries; interruption of these arteries inadequate functioning of the reimplanted arteries and the tamponade effect of increased cerebrospinal fluid (CSF) pressure due to hypertension in the proximal aorta play a role in the occurrence of spinal cord injury [3-5].

Moreover a steal phenomenon due to reversal of blood flow from radicular artery to aorta occurs following cross clamping, which enhances paraplegia due to a fall in perfusion pressure [6].
In the ringer lactate group, the results in neurological function and histopathological evaluation was significantly better than the control group, but not as good as in diltiazem + ringer lactate group. We think that vasodilatation as a result of aortic perfusion with ringer lactate, and counteraction against the steal phenomenon might hare provided a better circulation which may have been responsible this better score.

A number of preventive measures have been tried for the protection of the spinal cord during aortic surgery. Rapid and efficient surgical manipulation may shorten duration of cross clamping period. The importance of cross clamping duration had been stressed as early as in 1910. This technique was named later as "clamp and go" [7].

Livesay et al. [4] have shown that the risk of postoperative paraplegia increased from $3 \%$ to $11 \%$ whenever duration of cross clamping was longer than 30 minutes. Svensson et al. [8] have stressed to the importance of cross clamping duration as an independent risk factor.

Conflicting results have been reported regarding the relation of the cross clamping duration with the degree of spinal cord injury. Hollier et al. reported five cases of paraplegia in which cross clamping duration was less than 20 minutes [9]. In contrast Najafi reported no cases of paraplegia following 58 minutes of cross clamping [10]. Conflicting results may be due to poor description of the aneurism and its relation with the artery of localization of the Adamkiewitz.

Katz et al. [11] provided convincing evidence for the relationship between the duration aortic occlusion and the degree of neurological injury. They provided convincing evidence that 25-30 minutes is critical duration for cross clamping and the possibility of the neurological injury increases with larger duration and preventive measures become necessary.

Experimental evidence suggests that the spinal cord is efficiently protected if distal aortic pressure maintained between 60-70 mmHg [12]. By distal aortic perfusion it was aimed to increase spinal cord perfusion by increasing distal aortic pressure and provide a better spinal cord perfusion.

In most techniques distal aorta is perfused retrograde. Roller pump, passive shunt or centrifugal pumps atriofemoral and femoro-femoral shunts, or by means of a Gotts shunt $[8,13]$. Although distal aortic perfusion which was used in this study would not provide an adequate perfusion pressure it may be helpful for the deamine of metabolic wastes.

Reimplantation of major arteries of the spinal cord, particularly the artery of Adamkiewitch, to the aortic graft is believed to be preventive for the spinal cord injury [13].

Svenson et al. [14] recommended implantation of the segmental arteries between T8and L1in the pig model they have shown the section of arteries perfusing the spinal cord. Hollier and Moore [9] however recommended the 
implantation of all segmental arteries. In contrast preservation of these arteries greatly diminished the occurrence of paraplegia. Hence the spinal cord injury diminished. Therefore by isolated perfusion or by implantation of the spinal arteries into the graft.

Cross clamping of the aorta results with an increase in intraaortic pressure proximal to the occlusion, which in turn results in cardiac "back loading" and increase in CFS pressure. Blaidesell and Cooley argued that a rapid raise in intracranial pressure following cross clamping is the main cause leading to paraplegia. By compression over the vessels and neural tissue it causes a decrease in spinal cord perfusion pressure. Experimental evidence was provided that it decreases the risk for paraplegia $[15,16]$. According to the formula that; spinal cord perfusion pressure $=$ mean distal aortic pressure - CSF pressure, an increase in distal aortic pressure leads to an increase in spinal cord perfusion pressure.

A perfusion pressure of $50 \mathrm{mmHg}$ is the minimum value in (level by) which a normal spinal cord circulation can be maintained by auto regulatory mechanisms. Whatever it becomes impossible to keep perfusion pressure above this level a decrease in central venous pressure becomes effective in increasing the spinal cord perfusion pressure. Miyamoto et al. [17] were the fist to propose CSF drainage for prevention of spinal cord ischemia following cross clamping of the aorta. Now it is recommended as a standard procedure in high risk surgery of distal aorta $[18,19]$.

Besides increasing the perfusion pressure CSF drainage facilitates the elimination of neurotoxic waste products secreted into the spinal fluid after cross clamping.

Direct intrathecal administrations of some neuroprotective pharmacologic agents have been recommended, because their systemic administration results with intolerable side effects and organtoxicity. Ýntrathecal magnesium sulfate [20], and tetracaine [21] has been tried in combination with hypothermia for prevention of spinal cord ischemia.

A number of intrathecal vasodilators has been tried for the protection of the spinal cord. Ýntrathecal administration of papaverine has been shown to dilate the anterior spinal artery contributing to the protection of the spinal cord by increasing anterograde and securing the spinal cord segment perfused by Adamkiewitz artery. This phenomenon is unrelated to the efficacy of distal perfusion and the segmental origin of Adamkiewitz artery. Vasodilatation is not the sole effect of papaverine. It also blocs the calcium channels inhibits the electron transfer during oxidative phosphorilation, prevents the aerobic oxidation of the chemical substrates in Kreb's cycle, and prevents the formation of superoxyde free radicals and degradation of cyclic nucleotides [16,22]. In a monkey model Sun et al. [22] provided experimental evidence that intrathecal papaverine increases spinal cord circulation, and in no case paraplegia occurred after a 60 minute cross clamping of the aorta.

Maughan et al. [7] claimed that they have prevented spinal cord injury by intrathecal administration of $20 \%$ flusol-DA end oxygenated perfluoro-carbone.

There are experimental and clinical evidence that hypothermia has a protective effect on ischemic spinal cord injury [23,24]. Hyperthermia has been introduced into cardiovascular surgery and neurosurgery between 1950 and 1960 'es it is a useful and simple technique. Studies have shown that it promotes the protection of ATP reserves, stabilities the plasma membrane, inhibits neurotransmitter secretion and reuptake, diminishes post ischemic cerebral edema, and inhibits the formation of leucotriens [25-27]. Lei et al. [25] have shown that hypothermia causes a significant decrease in free radical formation.

Hypothermia can be induced systemically, of focally, that is inducing hypothermia in the spinal cord only local hypothermia can be induced through epidural intrathecal or intraaortic routes [28]. Svensson et al. [29] were unable to provide a protection by retrograde perfusion- of the spinal cord- through the azygos vein [29]. Svensson et al. [30] however induced local hypothermia in a pig model, by infecting and adenosine containing solution in normal saline into Para vertebral and spinal veins through azygos vein.

Hypothermia diminishes the energy consumption of neural tissue. Oxygen consumption diminishes by $5 \%$ for energy on centigrade degree fall in spinal cord temperature. Enzymatic reactions and metabolic needs of the neural tissue is diminished proportionally with the fall of its temperature. Under the reimplantation of the major arteries at least to the aortic graft will be preventive for the spinal cord injury [13]. Clinical investigation however indicates to the presence of technical difficulties in detecting these arteries preoperatively because of the occlusions or stenosis of these arteries. Svensson et al. [14] defended the reimplantation of segmental arteries between T8-L1, while Hollier et al. [9] defended the reimplantation of all arteries. Svensson et al. [13] provided experimental evidence in the pig experimental model.

The when the arteries perfusing spinal cord has been cut off a high rate of paraplegia occurred. in the pig model, and the neurological deficit strikingly decreased when these arteries are protected [13] isolated perfusion or reimplantation of spinal cord arteries into the graft is of particular importance for the prevention of spinal cord injury. Cross clamping of the aorta leads to with an increase in the intraaortic pressure with in turn causes a cardiac back loading and an increase in CSF pressure.

Total cardiopulmonary bypass and deep hypothermic circulatory arrest has been recommended for protection of the spinal cord during descending thoracic and thoracoabdominal aortic surgery [28]. However hemorrhage and pulmonary and nervous system 
complication prevents is widespread use [29]. Induced systemic or local hypothermia seems to be the most efficient technique for preservation of ischemic neural damage. the fall every in centigrade degree of temperature leads to a prolongation of ischemic damage by 5-6 minutes systemic and local hypothermia seem to be equal effective in protection of the spinal cord, but systemic hypothermia carries the risk for cardiac complication and coagulopaty. Regional spinal hypothermia can be accomplished by cooled blood or crystalloid perfusion through cooled liquid perfusion spinal cord vessels or by subarachnoid or epidence fluid perfusion [30].

We have found lower temperature values in groups $\mathrm{C}$ and $\mathrm{D}$ towards the end of the perfusion in which distal aortic perfusion ringer lactate at room temperature was performed perfusion we think that a fall in body temperature by the perfusion of hypothermic fluid may be important in producing a better outcome in neurological function.

In summary, in multitude of techniques have been used for protection of the spinal cord during aortic surgery some of which have been found of to clinical utility. We are of the opinion that utilization of the ringer lactate and diltiazem may be clinically beneficial.

Experimental model: Three sort of in experimental models been used during which spinal cord ischemia is expected to occur:

1. Intraaortic infrarenal aortic occlusion;

2. Direct clamping of the aorta with retroperitoneal approach following a flank incision;

3. Direct clamping of the aorta by transperitoneal approach following laparotomy.

We have used intraaortic balloon occlusion because we have found thin advantages for several reasons:

1. Less surgical manipulations is need in flank incision an addition femoral incision is needed for distal aortic pressure we have used the same incision for venous catheterization;

2. Less anesthetic use because of shorten duration of the surgical manipulation. Long term anesthetic may lead to hemodynamic instability and more ischemic hazard;

3. Intubation (intratracheal) is not required in contrast with flank incision and laparatomy which is more difficult for experimental animals to tolerate (which is less was tolerated by experimental animals);

4. Experimental material is more readily available;

5. Respiratory problems occur more frequently during intraabdominal surgery;

6. Occlusion device with double lumen with a balloon inflatable at a constant radius (width) renders ear artery catheterization unnecessary and diminishes the number and duration of surgical intervention and aortic rupture due to uncontrolled inflation of balloon will be prevented;
7. Intervention is quite practical as long as the experimental animal is at low weight.

Some disadvantages of the intraaortic occlusion however needs to be meintoined.

1. Risk of arterial rupture and impaired hemodynamics due to arteriotomy. In low weight animals procedure is particularly difficult because of small femoral artery;

2. Uncontrolled hemorrhage was occur due to uncontrolled inflation of the balloon;

3. Inappropriate gaugage and size the catheter;

4. In neurological evaluation of animal's lower Tarlovs scores may occur because of the incision of left lower extremity.

We think as a result diltiazem is effective to protection of medulla spinalis. We think this effect should be due to its effect on calcium metabolism of cell.

We tried to get experience with diltiazem for to save spinal cord. But also we earned a model practice skill about a model of occlusion of aorta.

\section{REFERENCES}

1. Tarlov IM. Acute spinal cord compression paralysis. J Neurosurg. 1972;36(1):10-20.

2. Danielisova V, Chavko M. KB-2796, a calcium channel blocker, ameliorates ischemic spinal cord damage in rabbits. Neurochem Res. 1994;19(12):1503-7.

3. Grubbs PE Jr, Marini C, Toporoff B, Nathan I, Basu S, Acinapura AJ, et al. Somatosensory evoked potentials and spinal cord perfusion pressure are significant predictors of postoperative neurologic dysfunction. Surgery. 1988;104(2):216-23.

4. Livesay JJ, Cooley DA, Ventemiglia RA, Montero CG, Warrian RK, Brown DM, et al. Surgical experience in descending thoracic aneurysmectomy with and without adjuncts to avoid ischemia. Ann Thorac Surg. 1985;39(1):37-46.

5. Symbas PN, Pfaender LM, Drucker MH, Lester JL, Gravanis MB, Zacharopoulos L. Cross-clamping of the descending aorta. J Thorac Cardiovasc Surg. 1983;85(2):300-5.

6. Dasmahapatra HK, Coles JG, Wilson GJ, Sherret H, Adler S, Williams WG, et al. Relationship between cerebrospinal fluid dynamics and reversible spinal cord ischemia during experimental thoracic aortic occlusion. J Thorac Cardiovasc Surg. 1988;95(5):920-3.

7. Maughan RE, Mohan C, Nathan IM, Ascer E, Damiani P, Jacobowitz IJ, et al. Intrathecal perfusion of an oxygenated perfluorocarbon prevents paraplegia after aortic occlusion. Ann Thorac Surg. 1992;54(5):818-24. 
8. Svensson LG, Crawford ES, Hess KR, Coselli JS, Safi HJ. Experience with 1509 patients undergoing thoracoabdominal aortic operations. Vasc Surg. 1993;17(2):357-68.

9. Hollier LH, Moore WM. Avoidance of renal and neurologic complications following thoracoabdominal aortic aneurysm repair. Acta Chir Scand Suppl. 1990;555:129-35.

10. Najafi H. 1980: descending aortic aneurysmectomy without adjuncts to avoid ischemia. 1993 update. Ann Thorac Surg. 1993;55(4):1042-5

11. Katz NM, Blackstone EH, Kirklin JW. Incremental risk factors for spinal cord injury following operation for acute traumatic aortic transection. Thorac Cardiovasc Surg. 1981;81(5):669-74.

12. Kouchoukos NT. Spinal cord ischemic injury: is it preventable? Semin Thorac Cardiovasc Surg. 1991;3(4):323- 8.

13. Svensson LG, Patel V, Robinson MF, Ueda T, Roehm JO Jr, Crawford ES. Influence of preservation or perfusion of intraoperatively identifed spinal cord blood supply on spinal motor evoked potentials and paraplegia after aortic surgery. J Vasc Surg. 1991;13(3):355-65.

14. Svensson LG, Hess KR, Coselli JS, Safi HJ, Crawford ES. A prospective study of respiratory failure after high-risk surgery on the thoracoabdominal aorta. J Vasc Surg. 1991;14(3):271-82.

15. Mauney MC, Blackbourne LH, Langenburg SE, Buchanan SA, Kron IL, Tribble CG. Prevention spinal cord injury after repair of the thoracic or thoracoabdominal aorta. Ann Thorac Surg. 1995;59(1):245-52.

16. Gharagozloo F, Larson J, Dausmann MJ, Neville RF Jr, Gomes MN. Spinal cord protection during surgical procedures on the descending thoracic and thoracoabdominal aorta: review of current techniques. Chest. 1996;109(3):799-809.

17. Miyamoto K, Ueno A, Wada T, Kimoto S. A new and simple method for preventing spinal cord damage following temporary occlusion of thoracic aorta by dranining the cerebrospinal fluid. Cardiovasc Surg (Torino). 1960;1:188-97.

18. Svensson LG, Hess KR, D’Agostino RS, Entrup MH, Hreib $\mathrm{K}$, Kimmel WA, et al. Reduction of neurologic injury after high-risk thoracoabdominal aortic operation. Ann Thorac Surg. 1998;66(1):132-8.

19. Safi HJ, Winnerkvist A, Miller CC $3^{\text {rd }}$, Iliopoulos DC, Reardon MJ, Espada R, et al. Effect of extended cross-clamp time during thoracoabdominal aortic aneurysm repair. Ann Thorac Surg. 1998;66(4):1204-9.

20. Simpson JI, Eide TR, Schiff GA, Clagnaz JF, Hossain I, Tverskoy A, et al. Intrathecal magnesium sulfate protects the spinal cord from ýschemic ýnjury during thoracic aortic crossclamping. Anesthesiology. 1994;81(6):1493-9.

21. Wakamatsu H, Matsumoto M, Nakakimura K, Sakabe T. The effects of moderate hypothermia and intrathecal tetracaine on glutamate concentrations of intrathecal dialysate and neurologic and histopathological outcome in transient spinal cord ischemia in rabbits. Anesth Analg. 1999;88(1):56-62.

22. Sun J, Hirsch D, Svensson G. Spinal cord protection by papaverine and intrathecal cooling during aortic crossclamping. J Cardiovasc Surg (Torino). 1998;39(6): 839-42.

23. Rokkas CK, Cronin CS, Nitta T, Helfrich LR Jr, Lobner DC, Choi DW, et al. Profound systemic hypothermia inhibits the release of neurotransmitter amino acids in spinal cord ischemia. J Thorac Cardiovasc Surg. 1995;110(1):27-35.

24. Grabenwöger M, Ehrlich M, Simon P, Grimm M, Laufer G, Wollenek G, et al. Thoracoabdominal aneurysm repair: spinal cord protection using profound hypothermia and circulatory arrest. J Card Surg. 1994;9(6):679-84.

25. Lei B, Tan X, Cai H, Xu Q, Guo Q. Effect of moderate hypothermia on lipid peroxidation in canine brain týssue after cardiac arrest and resuscitation. Stroke. 1994;25(1):147-52.

26. Busto R, Dietrich WD, Globus MY, Valdés I, Scheinberg P, Ginsberg MD. Small differences in intraischemic brain temperature critically determine the extend of ischemic neuronal injury. J Cereb Blood Flow Metab. 1987;7(6):729-38.

27. Allen BT, Davis CG, Osborne D, Karl I. Spinal cord ischemia and reperfusion metabolism: the effect of hypothermia. J Vasc Surg. 1994;19(2):332-9.

28. Crawford ES, Coselli JS. Thoracoabdominal aneurysm surgery. Semin Thorac Cardiovasc Surg. 1991;3(4):300-22.

29. Svensson LG, Rickards E, Coull A, Rogers G, Fimmel CJ, Hinder RA, et al. Relationship of spinal cord blood flow to vascular anatomy during thoracic aortic cross-clamping and shunting. J Thorac Cardiovasc Surg. 1986;91(1):71-8.

30. Svensson LG Crawford ES. Aortic dissection and aortic aneurysm surgery: clinical observations, experimental ýnvestigations, and statistical analyses. Curr Probl Surg. 1993;30(1):1-163. 